\title{
A RADIOCARBON PERSPECTIVE ON GREENLAND ICE-CORE CHRONOLOGIES: CAN WE USE ICE CORES FOR ${ }^{14} \mathrm{C}$ CALIBRATION?
}

\author{
John Southon \\ Earth System Science Department, University of California, Irvine, California 92697, USA. Email: jsouthon@uci.edu.
}

\begin{abstract}
Some of the most valuable paleoclimate archives yet recovered are the multi-proxy records from the Greenland GISP2 and GRIP ice cores. The crucial importance of these data arises in part from the strong correlations that exist between the Greenland $\delta^{18} \mathrm{O}$ records and isotopic or other proxies in numerous other Northern Hemisphere paleoclimate sequences. These correlations could, in principle, allow layer-counted ice-core chronologies to be transferred to radiocarbondated paleoclimate archives, thus providing a ${ }^{14} \mathrm{C}$ calibration for the Last Glacial Maximum and Isotope Stage 3, back to the instrumental limits of the ${ }^{14} \mathrm{C}$ technique. However, this possibility is confounded by the existence of numerous different chronologies, as opposed to a single (or even a "best") ice-core time scale. This paper reviews how the various chronologies were developed, summarizes the differences between them, and examines ways in which further research may allow a ${ }^{14} \mathrm{C}$ calibration to be established.
\end{abstract}

\section{INTRODUCTION}

The GISP 2 and GRIP ice cores were drilled $3 \mathrm{~km}$ to bedrock in the early 1990s by US and European teams operating at sites $30 \mathrm{~km}$ apart near the ice divide at Summit, central Greenland. The combined project represented the culmination of decades of Greenland ice drilling, and the cores were investigated in unprecedented detail. A comprehensive selection of the results were published in 1997 in a special edition of Journal of Geophysical Research ( $\mathrm{Vol} \mathrm{102,} \mathrm{nr} 12$ ), and data files and other information were also distributed as a CD-ROM (The Greenland Summit Ice Cores CD-ROM [1997], hereinafter the Summit CD-ROM). The complete CD-ROM contents are available on the Internet at http://www.ngdc.noaa.gov/paleo/icecore/greenland/summit/. In addition, the complete GISP2 $\delta^{18} \mathrm{O}$ data set (Grootes et al. 1993; Stuiver et al. 1995; Stuiver and Grootes 2000), including high-resolution data produced since 1997, is available at http://depts.washington.edu/qil/datasets/.

\section{ICE CORES AND THE RADIOCARBON CALIBRATION}

Many of the isotopic, physical, and chemical properties of the ice exhibit annual cycles that can be counted to establish an annual chronology. For example, density variations appear in summer snow layers caused by buildup of hoar layers due to snow subliming and recrystallizing in fair weather or by frost buildup on clear nights (Alley et al. 1997). $\delta^{18} \mathrm{O}$ records (Johnsen et al. 1992; Dansgaard et al. 1993; Grootes et al. 1993; Stuiver et al. 1995; Stuiver and Grootes 1997) show seasonal variations caused by summer-winter differences in cloud temperatures during snow formation. The record of electrical conductivity (ECM), which measures the current flowing across a potential difference of several $\mathrm{kV}$ between 2 electrodes dragged across a microtomed ice surface, shows strong annual cycles of acidity (Taylor et al. 1997). Concentrations of dust also vary seasonally, and layers can be identified directly or from instrumental records of light transmission or of laser-light scattering (LLS) from meltwater samples or intact ice (Hammer et al. 1997; Alley et al. 1997; Ram and Illing 1994; Ram and Koenig 1997). Concentrations of many chemical species also show strong annual cycles (Fuhrer et al. 1993).

The potential significance of these records for radiocarbon calibration arises from the close correspondence between centennial to millennial stadial-interstadial variations in ice-core climate proxies, notably $\delta^{18} \mathrm{O}$, and those in other climate archives containing material suitable for ${ }^{14} \mathrm{C}$ dating. The agreement becomes compelling if a good correlation is accompanied by a good story, i.e., if the 2 records show a detailed correlation over an extended period, and the linkage between the two can be explained by a plausible and direct mechanism. In such cases, the absolute time scale of counted 
annual ice-core layers can be mapped on to ${ }^{14} \mathrm{C}$-dated records via the common climate events, to establish an ice-core ${ }^{14} \mathrm{C}$ calibration analogous to the present tree-ring calibration (Spurk et al. 1998; Kromer and Spurk 1998; Stuiver et al. 1998) but extending further back in time.

A variety of detailed paleoclimate records are available that contain ${ }^{14} \mathrm{C}$-datable material and exhibit strong correlations with GISP2 and GRIP. Most obviously, marine sediment records proximal to Greenland (Voelker et al. 1999; van Krefeld et al. 2000) are strongly affected by the atmospheric and ocean circulation changes and the episodes of ice-rafting that took place during DansgaardOeschger (D-O) cycles. Variations in the meridional temperature gradient over the North Atlantic change the position of the Intertropical Convergence Zone and drive large stadial-interstadial changes in tropical Atlantic marine sediments (Peterson et al. 2000; Hughen et al. 2004). Atmospheric teleconnections transmit stadial-interstadial changes to distant Northern Hemisphere areas such as the NE Pacific, where changes in the Santa Barbara Basin sediment record also correlate closely with D-O events (Behl and Kennett 1996). Strong correlations with Greenland are also found in speleothem $\delta^{18} \mathrm{O}$ records from as far afield as the Indian Ocean and eastern China, where stadial-interstadial variations are attributed to changes in monsoon strength affecting the balance of summer versus winter precipitation (Wang et al. 2001; Burns et al. 2003). These and numerous other climate archives represent candidates for such an ice-core-based ${ }^{14} \mathrm{C}$ calibration, though subject to complications such as marine ${ }^{14} \mathrm{C}$ reservoir effects (ocean sediments) and incorporation of ${ }^{14} \mathrm{C}$-free geologic carbonate (speleothems).

However, all such calibrations are only as good as the ice-core time scales, and ice-core chronologies differ in several important respects from the dendro-time scale which underpins the present ${ }^{14} \mathrm{C}$ calibration. Tree rings are usually annual structures, whereas most of the ice-core indicators (dust, density layers, ionic concentrations, etc.) are laid down in multiple episodes within $1 \mathrm{yr}$ or season, and this can introduce counting ambiguities. Indicators such as dust or acidity can also be perturbed by one-time events such as volcanic eruptions. All ice-core proxies are also potentially vulnerable to wind erosion or to redeposition of blowing snow, and to melting or sublimation of annual layers, though reworking causes few problems under today's conditions at Summit (Meese et al. 1997). For at least some indicators, measurement of the record cannot be repeated because ice-core properties change under storage: for example, parts of the GISP2 LLS record of dust concentrations are compromised because microbubbles have appeared in stored Pleistocene ice which was initially clear (Ram et al. 2000).

In addition, since ice flows radially away from the Summit drilling sites to ablation and iceberg calving margins, annual layers become progressively thinner down core, and so the number of effective seasonal indicators decreases with depth. Cycles which are smoothed by diffusion $\left(\delta^{18} \mathrm{O}\right.$, some ions) and records of proxies such as ionic concentrations which are resolution-limited due to sample size constraints, are only useful at relatively shallow depths. Annual cycles in continuous-measurement records of ECM and visual stratigraphy persist in deeper core sections, but eventually these too become difficult to distinguish. The only counting chronologies available beyond $60 \mathrm{kyr}$ are singleparameter chronologies based solely on LLS (Meese et al. 1997; Ram and Koenig 1997).

Perhaps the most important difference, though, is that dendro-chronologies are based (at least ideally) on counting of numerous replicate trees, whereas the enormous effort involved in ice-core drilling and processing makes replication extremely difficult. Thus, whereas problems of missing, subannual, or hard-to-interpret rings in dendro-series can often be resolved by counting multiple records so that an absolute chronology accurate to within a year can eventually be constructed, this is almost impossible with ice cores. Every effort was made to address this problem at Summit, in 
terms of the basic decision to drill 2 holes, in the efforts by both GISP2 and GRIP investigators to count multiple climate proxies rather than a single indicator wherever possible, and in some cases by having multiple investigators count the same sections of core and attempt to reach consensus. As a result of the care taken, chronologies from different cores are synchronous to within a decade at least as far back as $3.1 \mathrm{kyr}$, as shown by comparisons between volcanic eruption markers in GISP2, GRIP, and the south Greenland Dye-3 core (Clausen et al. 1997; Zielinski et al. 1994). Nevertheless, for all but the past few thousand years, the fundamental difference remains: in favorable circumstances, a tree-ring chronology can be constructed which is close to absolute, whereas ice-core chronologies are subject to significant counting uncertainties.

\section{GISP2 AND GRIP CHRONOLOGIES}

\section{a) GISP2}

\section{1) Initial Counting Time Scale}

The GISP2 chronology was constructed using visual stratigraphy, LLS, and ECM to identify annual layers (Alley et al. 1993; Meese et al. 1994; Alley et al. 1997; Meese et al. 1997; Ram and Koenig 1997). $\delta^{18} \mathrm{O}$ data and chemical stratigraphy were also used in the upper part of the core. Layer counting was continuous except for some short breaks (typically corresponding to $10 \mathrm{yr}$ or less) due to core loss, mostly in the brittle ice zone about 3000-8000 BP. The lengths of these lost sections were known from drill logs, and layer thicknesses were interpolated to estimate the number of lost years (Alley et al. 1997). Sections of the core were counted by several different investigators to better estimate true counting uncertainties (Alley et al. 1997), and multi-parameter counts were used wherever possible in order to minimize the lack-of-replication problem. The results of this first attempt to establish a stratigraphic chronology (Meese et al. 1994) still provide the time scale for the upper part of the GISP2 core, though it has been superseded for depths below $2430 \mathrm{~m}$.

\section{2) $\delta^{18} \mathrm{O}_{\text {atm }}$ Correlation Time Scale}

Deeper in GISP2, even the visual stratigraphic and LLS records became problematic due to layer thinning. Bender et al. (1994) derived a time scale for the lower part of GISP2 by correlating $\delta^{18} \mathrm{O}_{\text {atm }}$ (the $\delta^{18} \mathrm{O}$ record of trapped atmospheric oxygen in the ice, as opposed to the $\delta^{18} \mathrm{O}$ of precipitation) with a similar record from the Antarctic Vostok core. Sowers and co-workers (Sowers et al. 1993) had correlated the Vostok record with the orbitally tuned chronology of the SPECMAP marine benthic $\delta^{18} \mathrm{O}$ record (Martinson et al. 1987). These records are expected to covary because deep ocean seawater $\delta^{18} \mathrm{O}$ variations arising from changes in global ice volume are transmitted to atmospheric oxygen by photosynthesis (Sowers et al. 1993). The correlations were not considered reliable for ages $<49$ kyr BP since the GISP2 and Vostok $\delta^{18} \mathrm{O}_{\text {atm }}$ records show little variation from 25 to $49 \mathrm{kyr}$. Uncertainties in relative ice ages at GISP2 and Vostok are quoted as $<3 \mathrm{kyr}$ including uncertainties in correlating gas records as well as errors in estimating the gas-ice age offsets caused by delayed bubble close-off (Bender et al. 1994). A direct correlation of GISP2 $\delta^{18} \mathrm{O}_{\text {atm }}$ with SPECMAP would clearly reduce the overall uncertainty, but the phasing of the orbital forcing-SPECMAP relationship, and hence the SPECMAP chronology itself, have been questioned (Shackleton 2000; Ruddiman 2003) and may be a source of significant additional error.

\section{3) Revised Stratigraphic Time Scale}

The derivation of this new chronology is described in detail by Meese et al. (1997). Briefly, comparison of the Bender et al. (1994) time scale with the preliminary counting chronology revealed very large differences, i.e., the $\delta^{18} \mathrm{O}_{\mathrm{atm}}$ time scale was $25 \mathrm{kyr}$ older than the stratigraphic chronology at 
$2800 \mathrm{~m}$. This indicated that the layer count in deeper core sections had been significantly underestimated, particularly during interstadials where dust concentrations were low. A visual stratigraphic recount produced no changes, but studies of a new high-resolution LLS record (Ram and Koenig 1997 - see below) indicated that more annual layers were present. This new LLS record was therefore counted independently between $2300 \mathrm{~m}$ and $2800 \mathrm{~m}$ by two analysts (D A Meese and A J Gow), and this recount provided most of the basis for a new stratigraphic time scale below $2300 \mathrm{~m}$, though some visual stratigraphic and ECM data were also used. This new chronology (Meese et al. 1997; file gispcountage.txt on the Summit CD-ROM) diverges from the old count below about $2380 \mathrm{~m}$. Counting errors are quoted as $\pm 10 \%$ below $2500 \mathrm{~m}$, based on a consistent $20 \%$ difference in the layer counts in this region by the two analysts, whose results were averaged to produce the stratigraphic chronology shown in Figure 1.

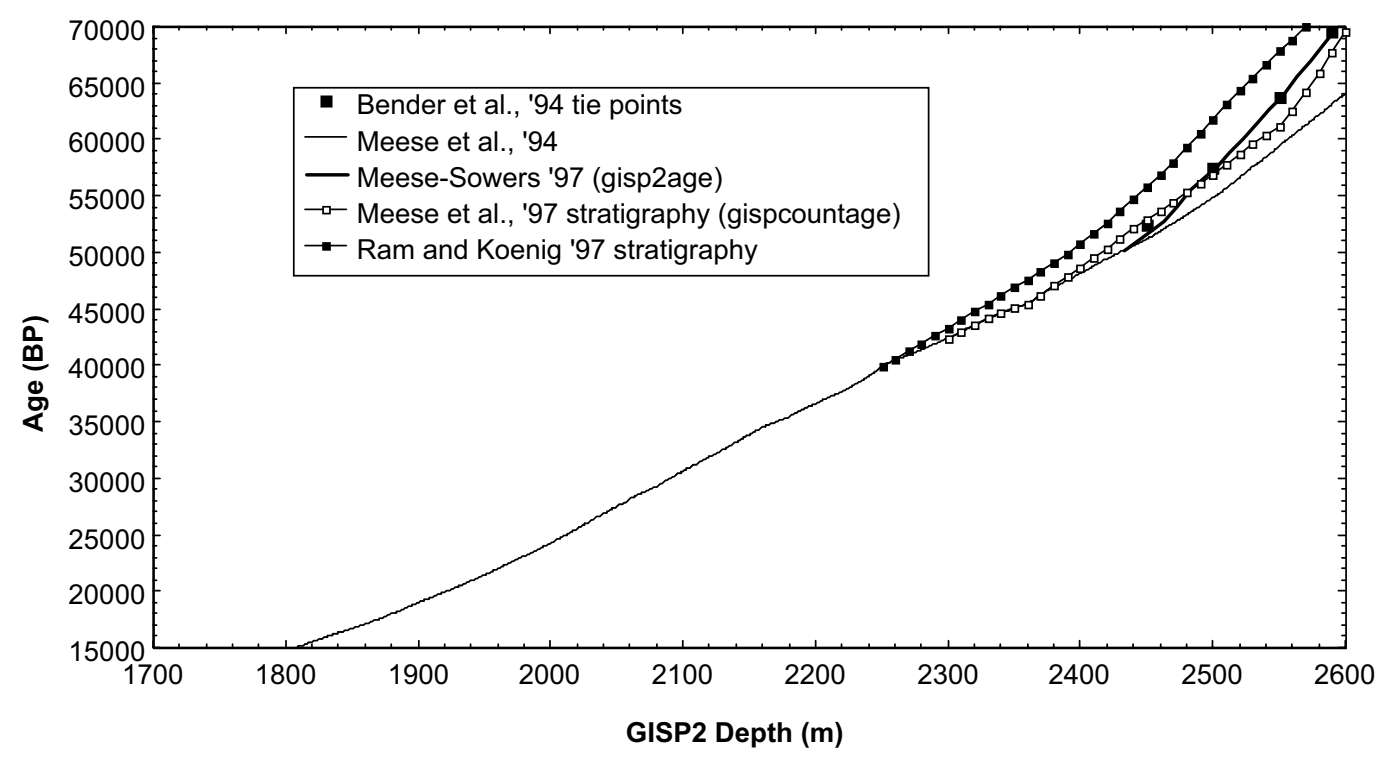

Figure 1 GISP2 age-depth relationships for the Glacial period

\section{4) "Official” (Meese-Sowers) Time Scale}

In light of these new data, counting results were combined with the Bender et al. (1994) correlative chronology to produce the "official" or Meese-Sowers time scale (Meese et al. 1997; file gisp2age.txt on the Summit CD-ROM) which is used for essentially all of the published GISP2 data. The counting cutoff point is often cited as $38 \mathrm{kyr}$ (e.g. Johnsen et al. 2001), with the implication that the chronology is less reliable beyond that point. However, the Summit CD-ROM states that the chronology is based solely on counting to $2431 \mathrm{~m}$ or $50 \mathrm{kyr}$, close to the ${ }^{14} \mathrm{C}$ limit. (See also Figure 1 , which shows the transition from a chronology based on the original stratigraphic count at $2431 \mathrm{~m}$ to one based on the $\delta^{18} \mathrm{O}_{\text {atm }}$ correlation tie points at $2500 \mathrm{~m}$.) Nevertheless, counting difficulties did increase markedly beyond $40 \mathrm{kyr}$ as described above, and estimated counting errors rose from 1-2\% for sections corresponding to the period 0-40 kyr, to 5-10\% for $40-45 \mathrm{kyr}$, and $10 \%$ beyond $45 \mathrm{kyr}$. If these uncertainties are additive, the cumulative uncertainty for the Meese-Sowers time scale may be as much as $\pm 1700 \mathrm{yr}$ at $50 \mathrm{kyr}$ compared to $\pm 700 \mathrm{yr}$ at $40 \mathrm{kyr}$. 


\section{5) LLS Time Scale}

The initial LLS work to measure dust concentrations in GISP2 down to about $1800 \mathrm{~m}$ was carried out using laser light scattered at $90^{\circ}$ from meltwater samples (Ram and Illing 1994). However, it was subsequently found that excellent results with improved resolution could be obtained directly from intact ice using a laser-sensor rig mounted on a motorized carriage that was stepped along the core, typically in 1-mm increments (Ram et al. 1994; Ram and Koenig 1997). This technique was used for the entire pre-Holocene section of GISP2. Laser beam sizes between 1 and $8 \mathrm{~mm}$ were used on different core sections to reduce noise by averaging over local dust concentration non-uniformities while adequately resolving annual layers. A 1-mm beam was used for depths below $2554 \mathrm{~m}$, providing sufficient resolution to distinguish annual layers down to thicknesses of a few $\mathrm{mm}$, which, in principle, could allow the core to be counted almost to the bottom. In practice, the count below $2850 \mathrm{~m}$ was considered unreliable due to severe folding and distortion of the layers (Gow et al. 1997). In addition, the extraction of a layer count from the dust record in the lower part of the core is a difficult process requiring considerable interpretive skill (e.g. Meese et al. 1997: Figures 8 and $10)$.

Figure 1 shows the chronology produced by counting dust layers in the lowest $800 \mathrm{~m}$ of the core, starting from an assumed age based on the Meese-Sowers time scale of $39.9 \mathrm{kyr}$ at $2250 \mathrm{~m}$. The resulting age-depth scale is older than the official time scale, with an offset of about $3 \mathrm{kyr}$ at $50 \mathrm{kyr}$ and $4.5 \mathrm{kyr}$ at $60 \mathrm{kyr}$. This LLS time scale has not been published in table form, and even the lowresolution dust record available on the Summit CD-ROM uses the official time scale, not the RamKoenig count. No counting uncertainties are quoted, but the differences between the Ram-Koenig, Meese, and Gow counts from the same dust record suggest that the uncertainties for this (or any of the chronologies discussed here) are of the order of several thousand years at $50 \mathrm{kyr}$ and beyond.

The GISP2 chronologies for the Last Glacial Maximum (LGM) and Stage 3 are shown in Figure 1: the old and revised stratigraphic counts (Meese et al. 1994, 1997; Summit CD-ROM file gispcountage.txt), the official Meese-Sowers time scale (Meese et al. 1997; Summit CD-ROM file gisp2age.txt), and the Ram and Koenig (1997) LLS chronology. Tie points of the Bender et al. (1994) correlative time scale are also shown for ages $>50 \mathrm{kyr}$.

\section{b) GRIP}

\section{1) Holocene (Counting) Time Scales}

The GRIP time scale was initially determined back to 8560 BP (relative to 1950) by correlating volcanic acid fall-out horizons with corresponding features in the layer-counted South Greenland Dye-3 core (Hammer et al. 1986; Johnsen et al. 1992). The Holocene Dye-3 record is characterized by high accumulation rates and very strong seasonal cycles, and Hammer (1997) considers it the most precisely dated of all the Holocene Greenland core records. It should be noted, though, that an early attempt to extend the Dye-3 chronology back to the end of the Younger Dryas using the ECM record (Hammer 1986) resulted in a significant undercount, probably because annual layer thicknesses in the early Holocene section deceased to the point where the ECM resolution was insufficient (S Johnsen, personal communication; Alley et al. 1993: Table 2 caption). This illustrates 2 points: first, counting is difficult even under relatively favorable circumstances and the difficulties multiply with increasing depth; second, as new and improved techniques have been brought to bear, the records have typically become older as previously unresolved structure emerges, i.e., the ages assigned to a given depth have tended to increase with time. 
An independent chronology extending back to $3.8 \mathrm{kyr}$ has also been derived from the GRIP data itself by deconvoluting the $\delta^{18} \mathrm{O}$ record to remove the smoothing effects of diffusion (Johnsen et al. 1997).

For the period before $8560 \mathrm{BP}$, seasonal variations in concentrations of microparticles and several chemical species were counted in sections of the GRIP core (but not continuously - S Johnsen, personal communication) to establish a counting chronology extending back to $14.5 \mathrm{kyr}$ (Johnsen et al. 1992; Dansgaard et al. 1993). This produced a counting date of 11,500 BP for the end of the Younger Dryas (Johnsen et al. 1992). A value of 11,540 BP is frequently quoted, as is a date of $8600 \mathrm{BP}$ for the end of the Dye-3-based GRIP chronology, but these dates are relative to AD 1990 (see Table 1 footnote in Johnsen et al. 1992; also S Johnsen, personal communication), and hence they are not conventional BP ages.

The initial count has since been repeated at least twice- see below-and counting of the GRIP record is ongoing (S Johnsen, personal communication). Annual cycles in high-resolution $\mathrm{Ca}$ and ammonium records (Fuhrer et al. 1993) have been identified to establish a continuous multiparamater Preboreal counting chronology from the 8.2-kyr cold event (8170 BP in Dye-3) to the end of Younger Dryas at 11,504 BP (Johnsen et al. 2001).

2) $s s 09$

The most frequently used chronologies for the deeper sections of GRIP are a series of glaciological models developed by S Johnsen; in other words, most GRIP chronologies are not layer-counted time scales, though counting data do provide model constraints. The models contain 2 parts: an ice-flow model used to estimate layer thinning, and an assumed relationship between $\delta^{18} \mathrm{O}$ and precipitation (accumulation rate) calibrated from the layer-counted upper part of the core (Dansgaard et al. 1993). The ss09 model, still the most readily available and widely used of all of the GRIP chronologies (Johnsen et al. 1992; Dansgaard et al. 1993), was intended primarily to provide a chronology for the Glacial period and the Pleistocene/Holocene transition. It was principally constrained by 2 tie points: the end of the Younger Dryas at 11,500 BP based on the GRIP/Dye-3 layer count, and the timing of Isotope Stage 5d (the first cold period after the Eemian interglacial), which was assumed to be at $110 \mathrm{kyr}$ according to the Martinson et al. (1987) SPECMAP time scale. However, an additional tie point, at the cold event dated to $8170 \mathrm{BP}$ by counting, was used to force good agreement with the Holocene counting ages (S Johnsen, personal communication). For the Holocene, the bestfit model ages agree with those determined from counting to within a few decades-i.e., within the counting uncertainties.

Of all the GRIP time scales, ss09 is the only one that has so far been published in full tabular form. The Summit CD-ROM contains the ss09 age-depth scale (file gripage.txt) and $\delta^{18} \mathrm{O}$ record at $55-\mathrm{cm}$ resolution (gripd18o.txt), plus other data tied to the ss09 chronology. A point which is not widely appreciated is that ss 09 is a pure model chronology throughout, even for the Holocene (S Johnsen, personal communication); thus, the data files cited above give ages of $8130 \mathrm{BP}$ and 11,560 BP for the 8.2-kyr cold event and the end of the Younger Dryas, respectively, where the annual count (Johnsen et al. 1992) gave 8170 and 11,500 BP. However, it is important to reiterate that $40-60-\mathrm{yr}$ differences are well within the estimated uncertainties of the chronologies concerned. For completeness, and given its widespread use, this chronology is included in Figure 2 and subsequent illustrations in this paper, but the ss09 model has been superseded by an improved version (ss09sea), described in a later section. 


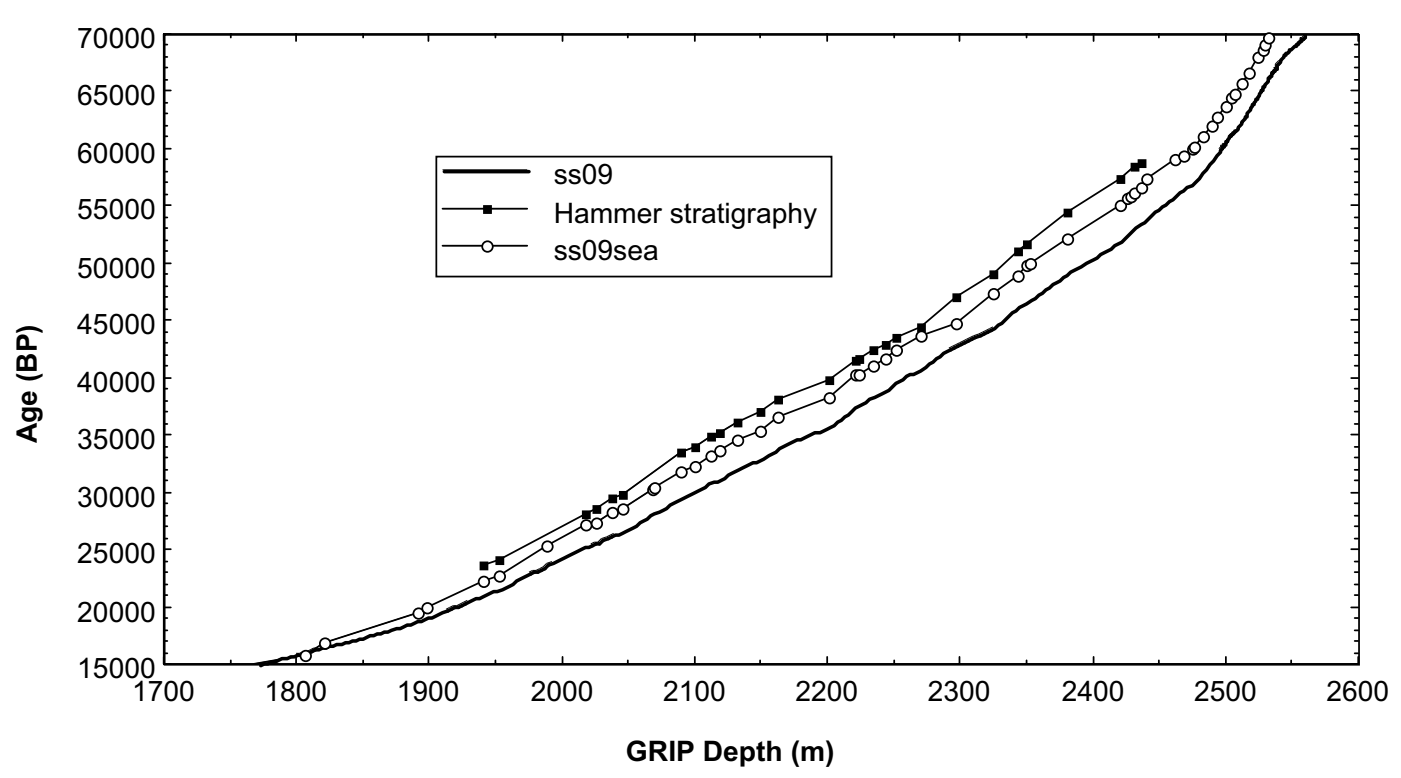

Figure 2 GRIP age-depth relationships for the Glacial period

\section{3) Dust Stratigraphy}

This chronology was developed by counting annual cycles in a record of dust concentrations, and is documented in a short unpublished University of Copenhagen report (Hammer 1997). The Dye-3 time scale was used back to $8170 \mathrm{BP}$, correlated to GRIP via volcanic acidity spikes. Most of the dust measurements were made at the drill site, and in order to keep up with the drilling output, the measurement resolution sometimes had to be decreased to the point where it was difficult to resolve annual layers. In addition, technical problems prevented layer counting over a few meters of core. In total, almost 40,000 annual layers were counted, spread out over the period 10 to $60 \mathrm{kyr}$, i.e., about $80 \%$ of the glacial section was actually counted. Beyond $60 \mathrm{kyr}$, the resolution decreased sufficiently that no reliable count could be made.

No complete version of this chronology has been published, but a list of tie points (stadial/interstadial transitions) is available in the 1997 report and on the Summit CD-ROM (file gripstrt.txt). Ages in the original report are relative to AD 1989, but those on the CD-ROM have been corrected to conventional BP ages relative to 1950. Uncertainties were evaluated from the cumulative differences between sectional counts, where a first count included and a second excluded all "annual" layers that were considered doubtful, and are quoted as $\pm 1700 \mathrm{yr}$ at $60 \mathrm{kyr}$.

4) $\mathrm{ss} 08 \mathrm{c}$

A new deglacial chronology developed by S Johnsen-ss08c — was introduced in the late 1990s (Johnsen et al. 1998; von Grafenstein 1999). Like ss09, it is basically a modeled chronology, but it is constrained by numerous tie points through the Bølling/Allerød/Younger Dryas/Preboreal period, based on multi-parameter counts of (primarily) dust, ECM, and nitrate concentrations. The deglacial/Preboreal counting data were discontinuous, i.e., effectively provided model targets for accumulation rates rather than fixed-age tie points, and the model-based accumulation rates were modified slightly to fit these observations (S Johnsen, personal communication). The ss08c chronology has not been published in tabular form, but was nevertheless adopted as the preferred deglacial ice- 
core chronology by the INTIMATE group of INQUA paleoclimatologists (Lowe et al. 2001) on the grounds that the GRIP 5-yr $\delta^{18} \mathrm{O}$ record - at that time the most detailed deglacial $\delta^{18} \mathrm{O}$ record available - was tied to ss $08 \mathrm{c}$. However, shortly thereafter, still more detailed $\delta^{18} \mathrm{O}$ data for the deglacial period became available from GISP2 (Stuiver and Grootes 2000).

5) ss09sea

Like the original ss09 which it supersedes, the new ss09sea or GRIP 2001 chronology (Johnsen et al. 2001) relies primarily on a 2-tie-point glaciological model, but a modified accumulation algorithm was used. Revised counting results for the Glacial/Holocene transition implied a shorter Bølling/Allerød than the earlier data on which ss08c was based, and this new algorithm improved the fit to the counting data. For the first time in GRIP, the age for the Younger Dryas termination tie point at 11,504 BP was based on a continuous count of annual layers through the Preboreal (S Johnsen, personal communication). The major ss09-ss09sea difference lies in the $\delta^{18} \mathrm{O}$-accumulation relationship assumed. The original ss 09 relied on measured $\delta^{18} \mathrm{O}$ values to predict accumulation, but ss09sea corrects for past shifts in seawater $\delta^{18} \mathrm{O}$ due to changes in global ice volume, which biased the calculated glacial accumulation rates in the earlier model. However, other possible variations in Summit $\delta^{18} \mathrm{O}$ due to temporal changes in the location of source regions for Greenland precipitation, or variations in conditions along the transport path (Charles et al. 1993) could not be evaluated since no sufficiently definitive picture exists of atmospheric and ocean circulation during glacial time. Thus, the accumulation model is still subject to some uncertainties. The Younger Dryas, Allerød, and Bølling are all longer in the new chronology than in ss09, and it gives significantly older ages for the LGM and Stage 3.

The 3 GRIP chronologies for the LGM and Stage 3 are shown in Figure 2. The dust stratigraphy ends at $60 \mathrm{kyr}$, and only the period $23 \mathrm{kyr}$ to $60 \mathrm{kyr}$ is shown, since no tie points were provided for the LGM. Note that since accumulation rates at GISP2 and GRIP are slightly different, depths of equivalent features in the 2 cores differ, and Figures 1 and 2 cannot be directly compared.

\section{CHRONOLOGIES COMPARED}

Table 1 gives an overall summary of the pre-Holocene chronological data, with ages for stadialinterstadial transitions (BP 1950) tabulated according to the different chronologies. Some of the interstadials that were numbered as single warming events by Dansgaard et al. (1993) have subsequently been resolved into doublets, which are denoted here as "a" and "b" events, and a minor interstadial between events 4 and 5 is labeled here as $4 \mathrm{~b}$. Data for the depths of transitions in the GRIP dust stratigraphy are taken from Hammer (1997) and are based on changes in dust concentrations. All other transition points shown represent midpoints of stadial-interstadial $\delta^{18} \mathrm{O}$ shifts, determined by inspection from the $\delta^{18} \mathrm{O}$ records for the 2 cores. Note that this difference in definitions is responsible for large mismatches in the lengths of Dansgaard-Oeschger events 12 and 14 between the dust and $\delta^{18} \mathrm{O}$-based GRIP chronologies (Table 1). In both of these long interstadials, dust levels rose sharply and electrical conductivity fell part way through a period of gradually falling $\delta^{18} \mathrm{O}$, well before the final sharp drop in the oxygen isotope ratios to full glacial values (an asynchronism which has serious implications for attempts to correlate variations in far-field climate records with Greenland $\mathrm{D}-\mathrm{O}$ cycles). A further difference is that the short $\delta^{18} \mathrm{O} \mathrm{D}-\mathrm{O}$ event $15 \mathrm{a}$ was not assigned as an interstadial in the dust stratigraphy. 


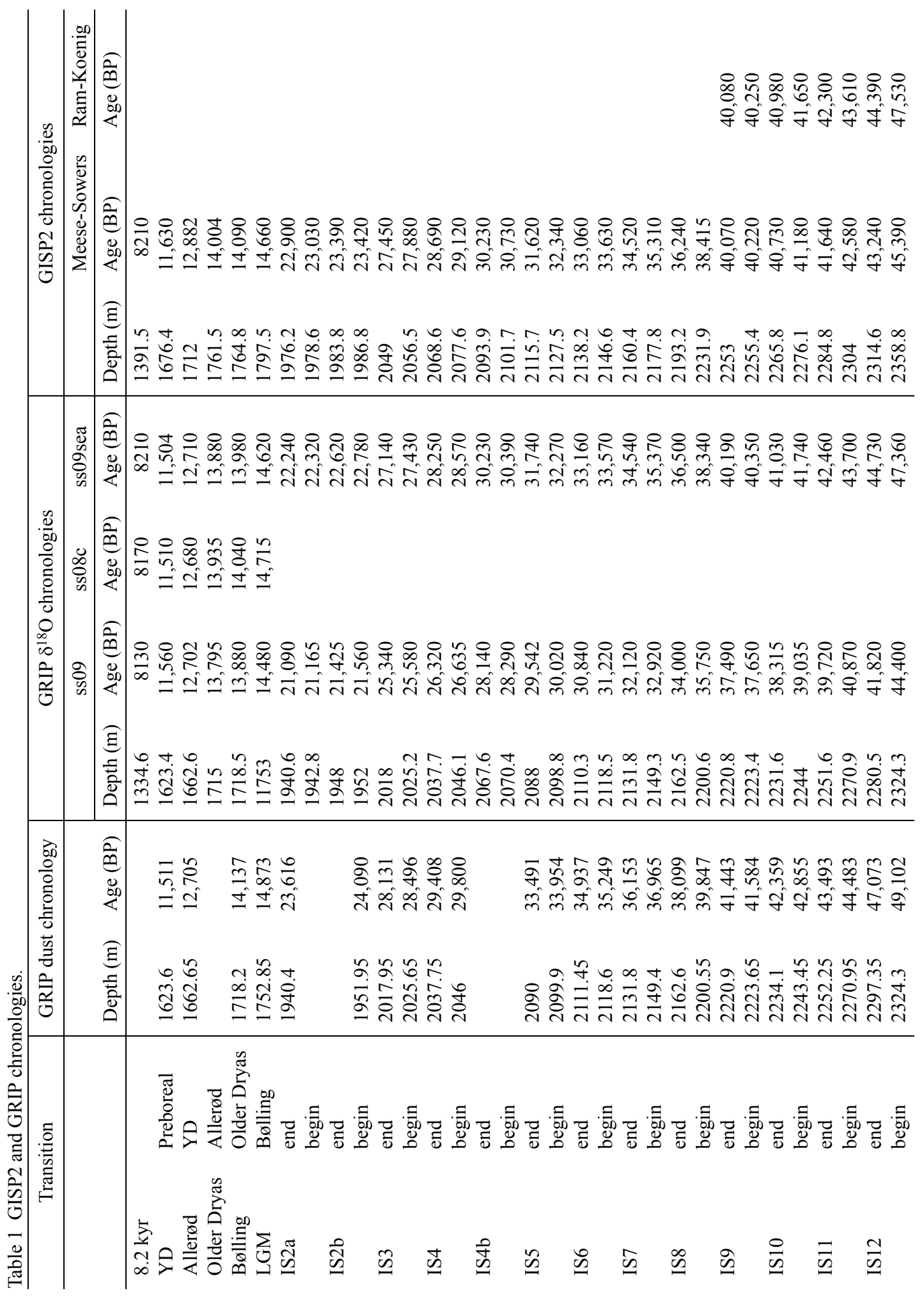




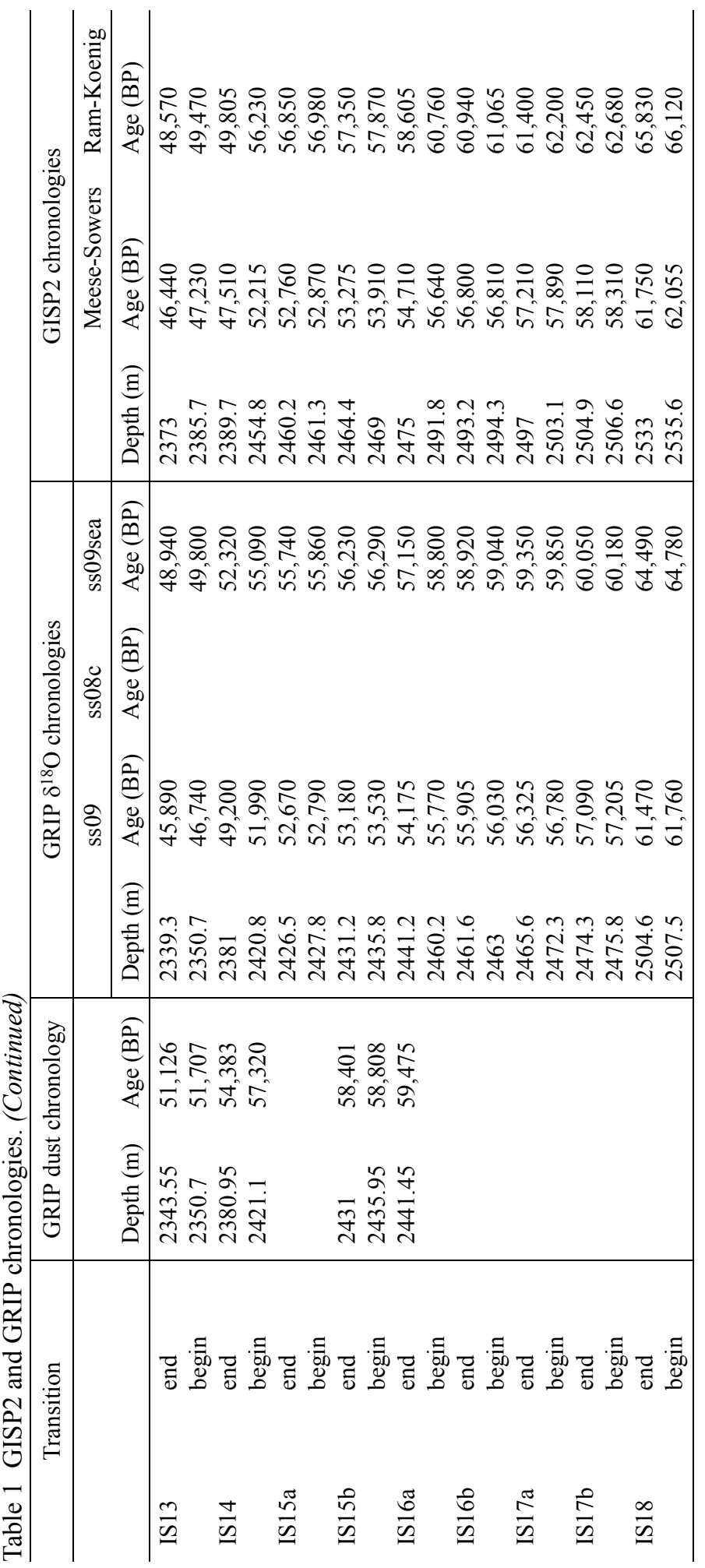




\section{1) Holocene}

Comparisons between volcanic acidity and sulphate records in GISP2, GRIP, and the south Greenland Dye-3 core (Clausen et al. 1997; Zielinski et al. 1994) show good agreement back to 3100 BP, but the GISP2 and GRIP chronologies diverge before that time. The different counting and modeling time scales for GRIP agree to within a few decades through the entire Holocene, but all place the end of the Younger Dryas between 11,500 and 11,560 BP, whereas the equivalent GISP2 date is around 11,640 BP. Roughly half of this overall discrepancy arises in a short period around $3400 \mathrm{BP}$, and there is evidence from ${ }^{10} \mathrm{Be}-{ }^{14} \mathrm{C}$ comparisons that GISP2 is on average about $60 \mathrm{yr}$ too old before that time.

${ }^{10} \mathrm{Be}$ and ${ }^{14} \mathrm{C}$ are both produced in the atmosphere by cosmic rays, but deposition of ${ }^{10} \mathrm{Be}$ is prompt (Raisbeck et al. 1981), while the recycling of ${ }^{14} \mathrm{C}$ via exchange between carbon reservoirs causes atmospheric ${ }^{14} \mathrm{C}$ concentrations to lag centennial-scale production changes. Carbon cycle models predict a 15 - to $20-\mathrm{yr}{ }^{10} \mathrm{Be}-{ }^{14} \mathrm{C}$ lag (Stuiver and Braziunas 1993; Bard et al. 1997), and a 15-yr shift was observed over the past $1000 \mathrm{yr}$ in well-dated Antarctic ice (Bard et al. 1997). However, fluctuations in the Holocene GISP2 ${ }^{10} \mathrm{Be}$ record, which extends back from $3300 \mathrm{BP}$ (Finkel and Nishiizumi 1997), lead $\Delta^{14} \mathrm{C}$ variations in the absolutely-dated tree-ring record (Stuiver et al. 1998) by about $80 \mathrm{yr}$ prior to $3400 \mathrm{BP}$, though unpublished late Holocene data show a lag of only 20-30 yr at 2400 and $2800 \mathrm{BP}$ (R Finkel, personal communication). The stability of this ${ }^{10} \mathrm{Be}-{ }^{14} \mathrm{C}$ shift prior to $3600 \mathrm{BP}$ (within \pm 20 to $30 \mathrm{yr}$ over $8000 \mathrm{yr}$ or more) suggests that for most of the Holocene, the precision of the GISP2 time scale is far better than the incremental counting uncertainties of $1-2 \%$ (Alley et al. 1997; Meese et al. 1997), though the overall uncertainty (i.e. with the single short problem area included) is consistent with the quoted errors.

The observed ${ }^{10} \mathrm{Be}-{ }^{14} \mathrm{C}$ differences imply that the GISP 2 chronology is about $60 \mathrm{yr}$ too old, starting some time between 2800 and $3400 \mathrm{BP}$. Evidence from $\delta^{18} \mathrm{O}$ suggests that the offset appears between 3300 and 3600 BP, probably around 3300-3400 BP (Southon 2002). This is illustrated in Figure 3, which shows smoothed GISP2 and GRIP ss09 $\delta^{18} \mathrm{O}$ results for the period 3000-5000 BP, with segments of the GISP2 record shifted chronologically as shown on the plot. GISP2 data older than about 3350 BP agree well with GRIP when shifted to younger ages by an average of about $70 \mathrm{yr}$, indicating that the GISP2 age offset probably appears close to that date. Interestingly, the period around 3300-3400 BP, and many (though not all) of the other intervals in Figure 3 where the GISP2ss09 offset appears to change by a few decades, correspond to regions of core loss in GISP2. (GRIP core recovery in the brittle ice zone was much better and almost no core was lost: Johnsen et al. 2001.) On this basis, it is tempting to relate these changes to errors in estimating how much core was lost in GISP2. However, this is an oversimplification at best: even if no core was lost between 3300 and $3400 \mathrm{BP}$ versus the estimated $40 \mathrm{yr}$ indicated in the data files, this accounts for less than half of the apparent GISP2-GRIP shift over this interval.

Whether or not poor core quality or core losses led to miscounting in a few short sections of GISP2, it is important to note that these core recovery problems occurred almost exclusively in the midHolocene brittle ice zone and do not have implications for the accuracy of the remainder of the GISP2 chronology. Furthermore, Holocene chronological problems are not confined to GISP2 alone. Recent comparisons of an unpublished GRIP ${ }^{10} \mathrm{Be}$ record with ${ }^{14} \mathrm{C}$ data indicate that GRIP time scales are several decades too young in the early Holocene (J Beer, personal communication). This confirms a discrepancy that was previously inferred from the GISP2 ${ }^{10} \mathrm{Be}-{ }^{14} \mathrm{C}$ offset and the $\sim 100$-yr age difference between the Preboreal GISP2 and GRIP $\delta^{18} \mathrm{O}$ records (Southon 2002). 


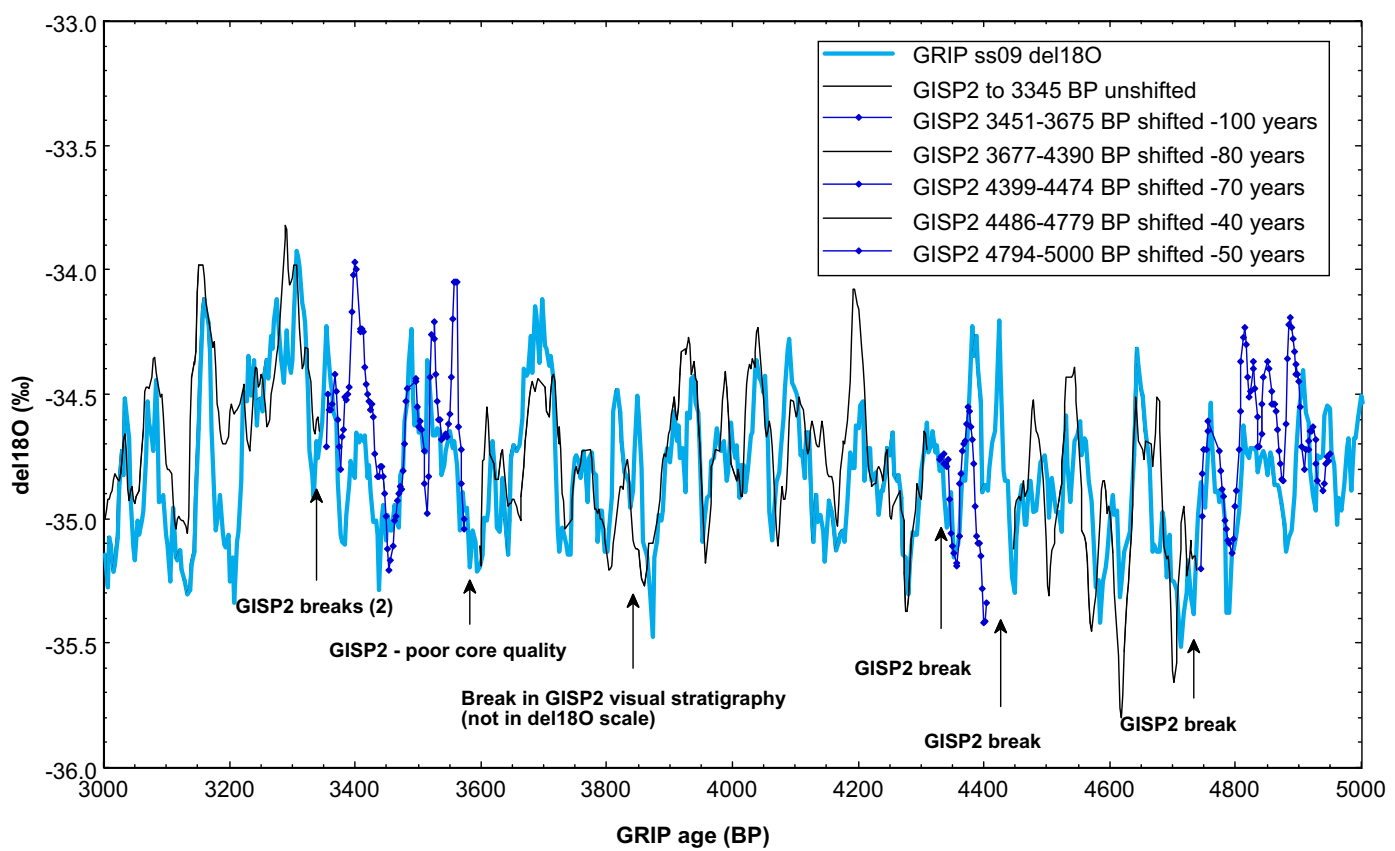

Figure 3 GISP2 and GRIP ss09 $\delta^{18} \mathrm{O}$ data for the period 3000-5000 BP. Temporal offsets between the 2 chronologies are close to zero in the late Holocene, but are $40-100 \mathrm{yr}$ before 3350 BP. Sections of the GISP2 record have been time-shifted to remove these offsets and are superimposed on the GRIP data.

\section{2) Deglaciation}

Published dendrochronological data from the German pine series indicate a date of 11,570 BP for the end of the Younger Dryas, based on a pronounced shift in ring widths suggesting a major amelioration of climatic conditions during the growing season (Friedrich et al. 2001). However, a recent reexamination of the pine record has resulted in a 20-yr shift to older ages before 11,300 BP (M Friedrich, personal communication). Figure 4 shows $\delta^{18} \mathrm{O}$ data for the deglacial period plotted according to the different time scales, which have been shifted to a common YD termination date of 11,590 BP. Detailed data for the GRIP dust stratigraphy are not shown due to lack of a sufficient number of tie points, but adjusted to the 11,590 YD termination, this chronology gives 12,784, 14,216, and 14,952 BP for the start of the YD, the Older Dryas, and the LGM-Bølling transition, respectively. The plotted $\delta^{18} \mathrm{O}$ records are closely synchronized back as far as $12,500 \mathrm{BP}$, but there is a sharp divergence before that time.

In particular, there are large differences in the length of the Allerød-YD transition, most notably between GISP2 and GRIP ss09 (Southon 2002). Interestingly, not only do the GRIP chronologies assign fewer years to the transition (about $150 \mathrm{yr}$ between the first drop from near-Holocene $\delta^{18} \mathrm{O}$ values and the $\delta^{18} \mathrm{O}$ minimum in GRIP ss09, versus $250 \mathrm{yr}$ in GISP2), but the transition in the GRIP core actually contains less ice. The second half of the transition spans about $2 \mathrm{~m}$ of core ( $1657 \mathrm{~m}$ to $1659 \mathrm{~m})$ in GRIP versus around $4 \mathrm{~m}(1705.5 \mathrm{~m}$ to $1709.5 \mathrm{~m})$ for the equivalent section of GISP2.

The discrepancies increase through the Allerød and the Bølling, so that the total spread between the various chronologies is almost $400 \mathrm{yr}$ at the LGM-Bølling transition (300 yr if the time scales are adjusted to a common YD termination as in Figure 4). A variety of independently dated climate records exist which contain signatures of the abrupt Bølling warming, including lake and marine 


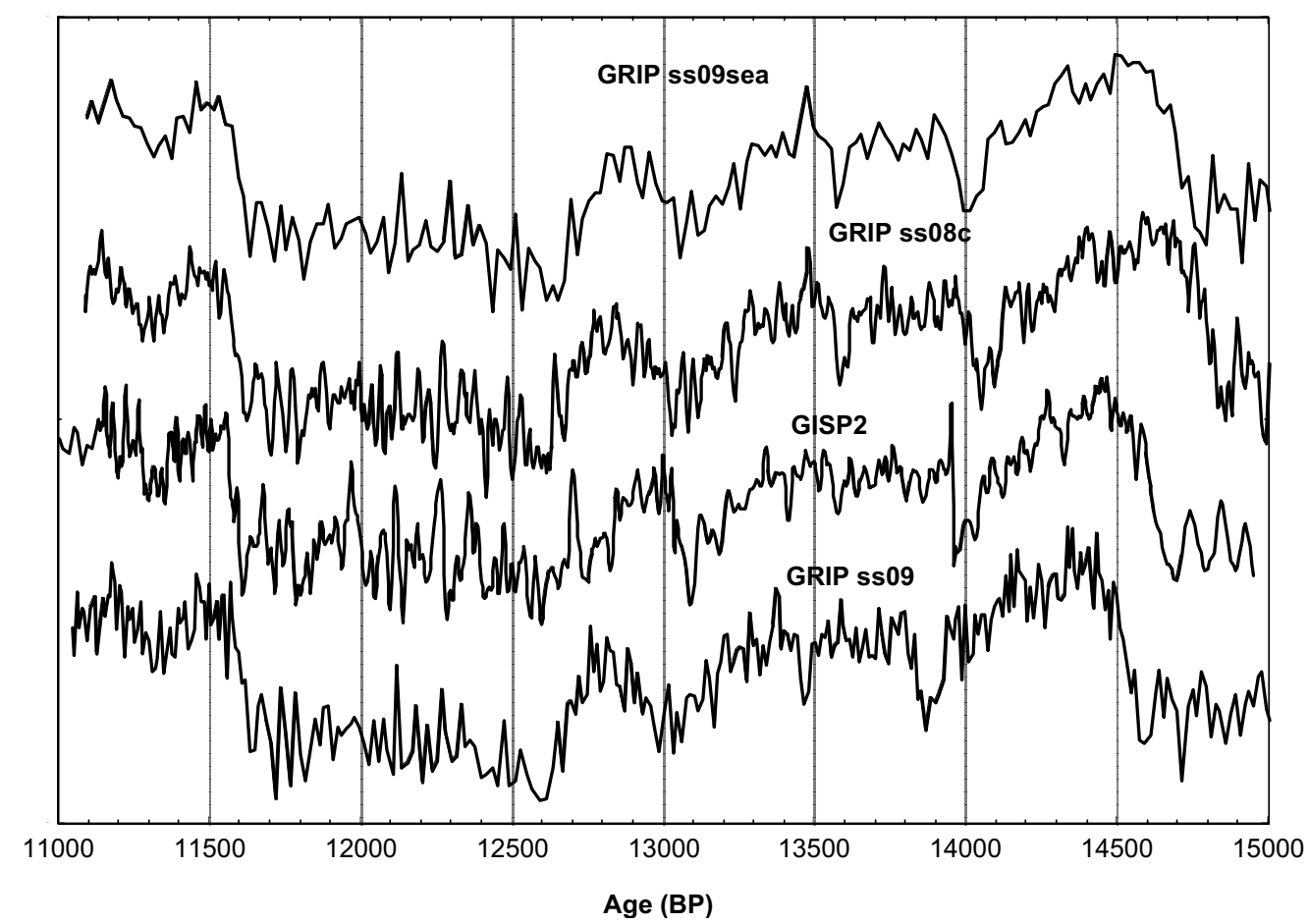

Figure 4 GISP2 and GRIP $\delta^{18} \mathrm{O}$ data for the deglacial period, with all chronologies adjusted to a common Younger Dryas termination date of 11,590 BP. Data for the GRIP dust stratigraphy (Hammer 1997) are not shown because very few tie points are available for this interval.

varves (Brauer et al. 1999; Hughen et al. 2000), U-Th-dated records of $\delta^{18} \mathrm{O}$ in speleothems (Wang et al. 2001), and many others. Unfortunately, these also scatter throughout this 400 -yr envelope and/ or have insufficient dating resolution to provide definitive support for one or other of the Greenland chronologies. However, work is proceeding to extend and strengthen a floating Bølling-Allerød tree-ring series from central Europe, which currently covers the entire period from the late Bølling to the early Younger Dryas, apart from a short gap in the early Allerød (M Friedrich, personal communication). If this gap can be closed, the series would provide a definitive value for the length of the Older Dryas-Younger Dryas interval. Since this ranges from about $1100 \mathrm{yr}$ in GRIP ss09 and GISP2 to $1400 \mathrm{yr}$ in the GRIP dust stratigraphy, a reliable estimate based on tree rings would provide an important indication as to which, if any, of these deglacial chronologies is correct.

\section{3) LGM and Stage 3}

Figure 5 shows the $\delta^{18} \mathrm{O}$ data plotted according to the different chronologies for the period 10 to $60 \mathrm{kyr}$. Two of the plots do not cover the full interval: the plot for the GRIP dust time scale omits the LGM because no tie points are available over that interval, and the Ram and Koenig dust chronology for GISP 2 only begins around $40 \mathrm{kyr}$. The data show age differences of the order of $10 \%$, with a total spread of $3 \mathrm{kyr}$ at $25 \mathrm{kyr} \mathrm{BP}$, rising to $4 \mathrm{kyr}$ at $40 \mathrm{kyr} \mathrm{BP}$ and $5 \mathrm{kyr}$ at $50 \mathrm{kyr} \mathrm{BP}$ and beyond. Even allowing for the fact that the shortest of these chronologies (GRIP ss09) has been superseded by the improved ss09sea model, the spread is still more than $4 \mathrm{kyr}$ at $50 \mathrm{kyr}$ BP. These discrepancies highlight just how difficult it is to extract an accurate count from these records, and suggest that the quoted uncertainties for the different time scales are certainly not overestimates. 


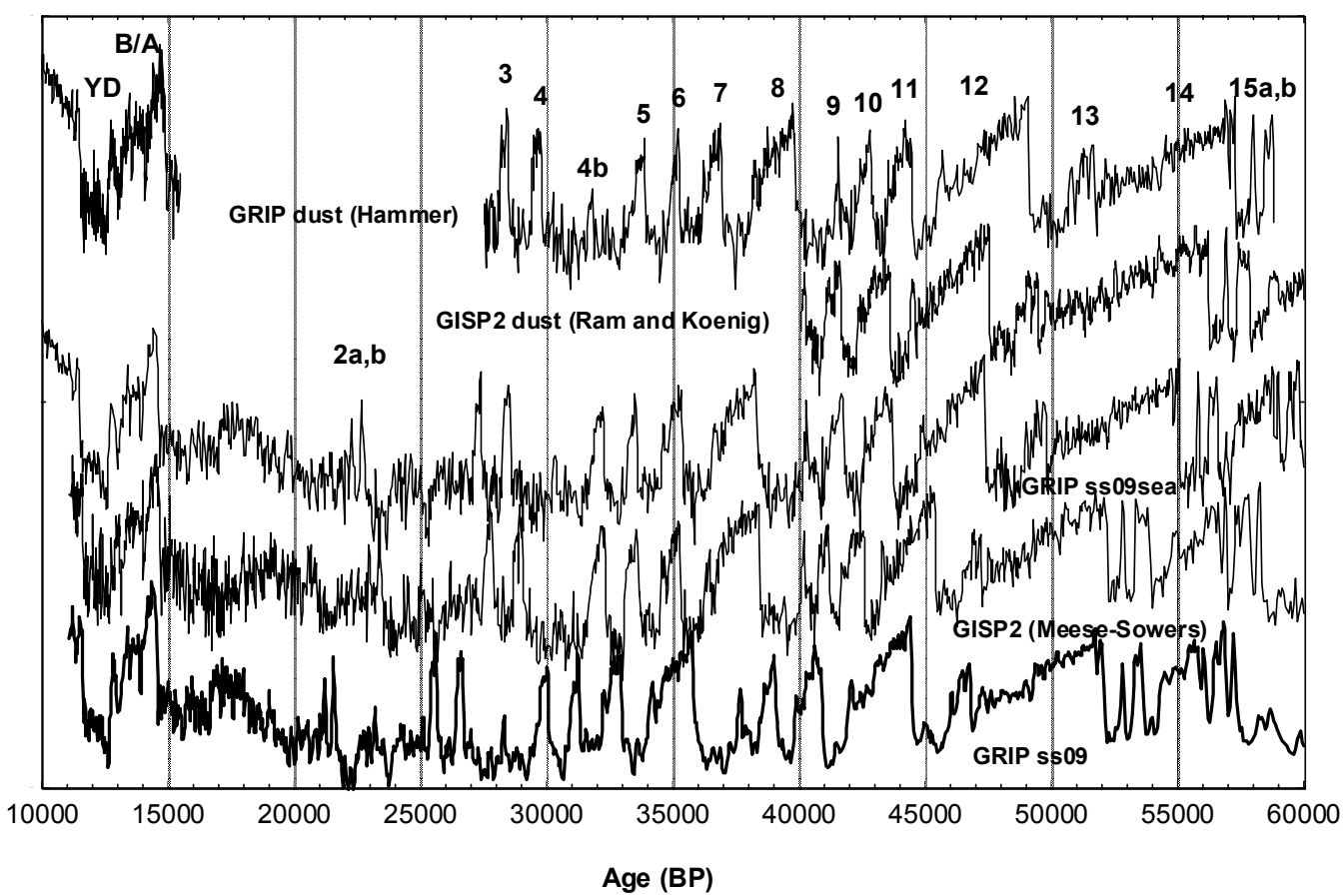

Figure 5 GISP2 and GRIP $\delta^{18} \mathrm{O}$ data for the period 10-60 kyr BP, with numbered Dansgaard-Oeschger events (interstadials) indicated.

\section{CALIBRATION OF ICE-CORE RECORDS}

Without additional information, it is not clear how to determine which, if any, of these glacial chronologies is correct. However, there are at least 2 possible ways in which one of these time scales could be validated. One way would be to demonstrate the presence of regular cycles that are well established in other records.

Parts of both the Holocene and the Pleistocene sections of the GISP2 dust profile exhibit strong modulation, with periods of approximately 11, 22, 91, and $200 \mathrm{yr}$, which Ram and coworkers (Ram et al. 1997; Ram and Stolz 1999) associate with the 11-yr (Schwabe), 22-yr (Hale), 80-90-yr (Gleissberg), and 200-yr (Suess) cycles which occur in sunspot numbers and the ${ }^{14} \mathrm{C}$ record. However, questions remain: the linkage between solar activity and dust levels is not well understood, and the very strong 11-yr modulation, which is clearly visible in portions of the record, is surprisingly absent from results of a Fast Fourier Transform analysis (Ram et al. 1997). Furthermore, since the lengths of historical sunspot cycles and the $\sim 11$-yr dust modulation cycles both vary by $\pm 25 \%$ (Ram et al. 1997), GISP2 chronological errors of $10 \%$ or so are still possible within this framework. Nevertheless, assuming these cycles are real and frequency-invariant, they provide a potential means for validating (or even tuning) the ice-core chronologies, and deserve further study.

Several investigators including Bond et al. (1997) and Rahmstorf (2003) have linked a periodicity of around $1500 \mathrm{yr}$ for rapid D-O warming events in GISP2 (Grootes and Stuiver 1997) with an underlying "pacing" cycle which is also associated with quasi-periodic increases over the Holocene in ice-rafted debris in the North Atlantic and other indications of climatic disturbance. In the most recent of these analyses (Rahmstorf 2003), cycle times for D-O events as far back as 40 kyr corre- 
spond precisely (typically well within 10\%) with a 1470-yr cycle according to the GISP2 time scale, but this regularity is lost when the GRIP ss09 chronology is used.

At first sight, this appears to validate the GISP2 chronology; however, there is no a priori reason to assume that cycle times for such climatic oscillations are fixed. Also, the climate fluctuations within the Holocene exhibit a variation in length of almost $\pm 40 \%$ (Bond et al. 1997), so that the true periodicity of the underlying forcing mechanism, if one exists, is poorly constrained. Thus, a fixed Pleistocene oscillation period may indicate that the GISP2 time scale is self-consistent, but does not necessarily prove that it is correct. Furthermore, since other researchers using different mathematical techniques (Alley et al. 2001) have extracted quasi-periodic $\sim 1500$-yr cycles from the GRIP data as well as from GISP2, it is clear that the results of such analyses are strongly algorithm-dependent.

Alternatively, independent dating may provide a temporal framework for the ice-core time scales, or at least a way of pinning them to a single fixed tie point. Note, however, that this second strategy represents a major retreat from the original idea of calibrating ${ }^{14} \mathrm{C}$ using ice cores, to a fallback position involving calibration of the ice-core chronologies themselves.

One possibility is to date Dansgaard-Oeschger events using U-Th dates from speleothem calcite records that show stable isotope variations correlated with Greenland $\delta^{18} \mathrm{O}$ changes. (Of course, comparison of ${ }^{14} \mathrm{C}$ and U-Th dates on speleothem calcite can provide a direct ${ }^{14} \mathrm{C}$ calibration without involving ice cores-e.g. Beck et al. 2000 - though subject to uncertainties in ${ }^{14} \mathrm{C}$ corrections for geological carbonate). Three of the most recent, detailed, and convincing speleothem-Greenland comparisons are from Hulu Cave in eastern China (Wang et al. 2001), Spa Cave in the Austrian Alps (Spotl and Mangini 2002), and Moomi Cave on the Indian Ocean island of Socotra (Burns et al. 2003). Of the two alternative Hulu Cave correlations presented for Stage 3, the older is by far the more convincing, and Hulu features identified with D-O events 17-20 appear to have been misidentified, so that the Stage 4 chronology is probably $1-4$ kyr older than reported (Wang et al. 2001; Figure 1). Under these assumptions, the Hulu record is older than GISP2 beyond $40 \mathrm{kyr}$ and is a good match with the GRIP ss09sea chronology. It is also in good agreement with the shorter Spa record (Spotl and Mangini 2002), which extends from the start of D-O event 12 back beyond D-O 15.

U-Th dates for the Socotra record, which covers D-O cycles 9-13, initially appeared significantly older than even the oldest of the Greenland time scales (Burns et al. 2003) and disagreed strongly with the Hulu data and with other U-Th results (e.g. Genty et al. 2003, and references therein). However, a recent reevaluation of the Socotra chronology (S Burns, personal communication) suggests that it too is consistent with GRIP ss09sea in the 40-50-kyr range. If these preliminary new Socotra results are confirmed, the close agreement between the 3 speleothem records and GRIPss09sea will be an important step towards establishing a validated Greenland chronology for Stage 3.

An alternative is to use $\mathrm{K}-\mathrm{Ar}$ and ${ }^{40} \mathrm{Ar} /{ }^{39} \mathrm{Ar}$ dates for the Laschamp geomagnetic excursion to pin the ice-core data. A ${ }^{10} \mathrm{Be}$ concentration spike is observed close to Dansgaard-Oeschger event 10 in both GISP2 (R Finkel, personal communication) and GRIP (Yiou et al. 1997) and is also seen in Vostok (Raisbeck et al. 1992) and in marine sediments (Castagnoli et al. 1995; Robinson et al. 1995; Frank et al. 1997). This global ${ }^{10} \mathrm{Be}$ increase is widely attributed to increased cosmogenic isotope production due to a large reduction in geomagnetic shielding during the Laschamp event. Other explanations have been proposed (e.g. Kocharov 1992), but the precise synchronism between a pronounced geomagnetic low and an intense $\Delta^{14} \mathrm{C}$ peak in the same sedimentary record (Voelker et al. 1998) seems compelling. If the assumption that the ${ }^{10} \mathrm{Be}$ peak represents a production spike is correct, dating the Laschamp event effectively dates D-O event 10. 
Table 2 shows $\mathrm{K}-\mathrm{Ar}$ and ${ }^{40} \mathrm{Ar} /{ }^{39} \mathrm{Ar}$ dating results from the Laschamp lava flow itself, from the nearby Olby flow which exhibits similar magnetic properties, and from Laschamp-correlative lavas on Iceland's Reykjanes Peninsula. Ages are weighted means with 1- $\sigma$ uncertainties. Single-measurement uncertainties $(1 \sigma)$ are typically 5-10 kyr for Laschamp-Olby and as high as 15-25 kyr for the Iceland flows due to the combined effects of low potassium content in the lavas and corrections for an atmospheric Ar component. Regardless of these uncertainties, the results clearly cluster around 45-46 kyr, several kyr older than the date for D-O event 10 in any of the Greenland chronologies.

Table $2 \mathrm{~K}$-Ar and ${ }^{40} \mathrm{Ar} /{ }^{39} \mathrm{Ar}$ dates for the Laschamp event and the ${ }^{10} \mathrm{Be}$ peak.

\begin{tabular}{llll}
\hline Method & Location & Reference & Mean age $(\mathrm{kyr} B P)^{\mathrm{a}}$ \\
\hline Dates for the Laschamp event & & \\
$\mathrm{K}-\mathrm{Ar}$ & Laschamp-Olby & Hall and York (1978) & $45.4 \pm 2.4(\mathrm{n}=10)^{\mathrm{b}}$ \\
${ }^{40} \mathrm{Ar} /{ }^{39} \mathrm{Ar}$ & Laschamp-Olby & Hall and York (1978) & $47.4 \pm 1.9(\mathrm{n}=4)^{\mathrm{b}, \mathrm{c}}$ \\
$\mathrm{K}-\mathrm{Ar}$ & Laschamp-Olby & Gillot et al. (1979) & $45.2 \pm 4.2(\mathrm{n}=10)$ \\
${ }^{40} \mathrm{Ar} /{ }^{39} \mathrm{Ar}$ & Laschamp-Olby & Levi et al. (1990) & $45.4 \pm 2.4(\mathrm{n}=2)^{\mathrm{d}}$ \\
${ }^{40} \mathrm{Ar}{ }^{39} \mathrm{Ar}$ & Reykjanes, Iceland & Levi et al. (1990) & $51.4 \pm 9.0(\mathrm{n}=5)^{\mathrm{d}}$ \\
${ }^{40} \mathrm{Ar} /{ }^{39} \mathrm{Ar}$ & Reykjanes, Iceland & Levi et al. (1990) & $40.9 \pm 4.3(\mathrm{n}=14)^{\mathrm{e}}$ \\
$\mathrm{Dates}$ for the & ${ }^{10}$ Be peak/Campanian Ignimbrite eruption \\
${ }^{40} \mathrm{Ar} /{ }^{39} \mathrm{Ar}$ & Tyrrhenian Sea & Ton-That et al. $(2001)$ & $41.1 \pm 1.1(\mathrm{n}=24)^{\mathrm{f}}$ \\
${ }^{40} \mathrm{Ar}{ }^{39} \mathrm{Ar}$ & Campi Flegrei, Italy & Deino et al. $(1994)$ & $37.4 \pm 0.2(\mathrm{n}=3)$ \\
${ }^{40} \mathrm{Ar} /{ }^{39} \mathrm{Ar}$ & Campi Flegrei, Italy & de Vivo et al. $(2001)$ & $39.28 \pm 0.6(\mathrm{n}=18)^{\mathrm{g}, \mathrm{h}}$ \\
\hline
\end{tabular}

${ }^{a}$ Weighted means plus $1-\sigma$ uncertainties.

${ }^{\mathrm{b}}$ One outlier excluded.

"Results from "high-precision" intermediate-temperature Ar fraction.

dMeasured at Oregon State University.

${ }^{\mathrm{e}}$ Measured at Gif-sur-Yvette.

fIsochron age, based on 24 of $51 \mathrm{Ar} / \mathrm{Ar}$ measurements.

gMultiple aliquots measured for some samples; 36 age determinations overall.

${ }^{\mathrm{h}}$ Two outliers excluded: mean age $=39.40 \pm 0.6 \mathrm{kyr}$ with outliers retained.

Also shown are results relating to the age of a thick marine tephra layer that appears throughout Tyrrhenian Sea sediments at depths corresponding to mid-Stage 3 (Ton-That et al. 2001) and bisects the concentration peak in the ${ }^{10} \mathrm{Be}$ record from sediment core CT 85-5 (Castagnoli et al. 1994). TonThat et al. (2001) have determined an $\mathrm{Ar} / \mathrm{Ar}$ isochron age of $41.1 \pm 1.1 \mathrm{kyr}$ for the tephra, but interpretation of this result is complicated by large uncertainties for individual measurements and by the presence of numerous outliers in the data. The tephra was originally associated with the Citara Tuff eruption, but is now identified on the basis of its size and its chemical composition with the cataclysmic Campanian Ignimbrite (CI) eruption from the Campi Flegrei near Naples (Ton-That et al. 2001). The CI has been ${ }^{40} \mathrm{Ar} /{ }^{39} \mathrm{Ar}$ dated to $37.4 \pm 0.2 \mathrm{kyr}$ (Deino et al. 1994), but most recently an exhaustive series of dates on multiple high-K (sanidine) samples from 12 different locations, with typical single-measurement uncertainties of just a few hundred years, yielded a mean age of $39.28 \pm 0.06 \mathrm{kyr}$ (de Vivo et al. 2001). Provided the linking of the tephra layer with the CI eruption is correct, these latest high-precision results which indirectly date the ${ }^{10} \mathrm{Be}$ spike raise serious doubts about the earlier dating of the Laschamp.

Another possibility would be to pin the chronologies by linking one or more well-dated Pleistocene volcanic eruptions directly with ice-core markers. The CI is an obvious candidate, but in the absence 
of compositional data from tephra shards in the ice cores, it is not clear which of several mid-Stage 3 peaks in the GISP2 and GRIP sulphate and acidity records (Zielinski et al. 1996; Gronvold et al. $1995)$ correspond to this eruption. A very prominent layer of ash and rhyolitic glass shards is found in the ice cores at depths corresponding to the middle of D-O event 15 (Ram et al. 1996; Gronvold et al. 1995). This shows similar composition to the widespread Z2 ash found in North Atlantic sediments and to the Thorsmork Ignimbrite on Iceland (Lacasse et al. 1996). Earlier ${ }^{40} \mathrm{Ar} /{ }^{39} \mathrm{Ar}$ measurements on the ignimbrite produced a surprisingly old date of $73 \pm 3 \mathrm{kyr}$ (Sigurdsson et al. 1998), but recent measurements on several samples yielded an isochron age and $1-\sigma$ uncertainty of $54.5 \pm 1 \mathrm{kyr}$ (W McIntosh, personal communication), which agrees at 2 standard deviations with both GISP2 and GRIP ss09sea.

\section{FUTURE PROSPECTS}

Given the current lack of consistency in the dating of potential tie points, it seems unlikely that the large discrepancies between the GISP2 and GRIP time scales can be resolved quickly, but one of several new developments might ultimately allow a definitive chronology to be developed. Multiparameter counting of the new NGRIP core from a location $300 \mathrm{~km}$ north of Summit is presently underway (Johnsen 2001). Layer thinning at NGRIP is less than expected due to basal melting, so prospects appear good that this core will exhibit well-resolved annual cycles far back into Stage 3 (S Johnsen, personal communication). In-situ LLS well-logging techniques, using laser light scattered at $180^{\circ}$ from dust layers around a borehole, may allow new records to be extracted from existing holes to help resolve ambiguities in currently available data. One such instrument has already produced new high-resolution records from GISP2 and NGRIP (Bay et al. 2003; B Price, personal communication). Effects of drill scars in the boreholes with a spacing close to the annual layer thicknesses have thus far precluded any derivation of an annual chronology, but, in principle, these could be removed by adding a "polisher" to the logging package, or mathematically during data analysis (B Price, personal communication). Alternatively, further U-Th dating of speleothem isotopic records may reach a consensus and generate a temporal framework for Dansgaard-Oeschger events; or definitive Ar/Ar dating of the Laschamp event, or association of a well-dated volcanic eruption with an ice-core signal, could fix at least 1 time point to which the various chronologies can be tied.

\section{CONCLUSIONS}

Significant differences exist between the various GISP2 and GRIP chronologies, with offsets that are at least as large as the stated uncertainties. For the Holocene, $\delta^{18} \mathrm{O}$ data from the 2 cores show good agreement back to $3300 \mathrm{BP}$. However, an offset of about $80 \mathrm{yr}$ is present before $3600 \mathrm{BP}$, and ${ }^{10} \mathrm{Be}-{ }^{14} \mathrm{C}$ comparisons suggest that GISP2 is about $60 \mathrm{yr}$ too old before $3400 \mathrm{BP}$. The Holocene model and layer counting time scales for GRIP all agree within counting errors, but they date the end of the Younger Dryas 100-150 yr later than in GISP2. When the various chronologies are pinned to the current tree-ring date of 11,590 BP for the end of the Younger Dryas, they are in excellent agreement back to $12,500 \mathrm{BP}$, but diverge prior to that date, with a spread of $100 \mathrm{yr}$ at the start of the YD and several hundred years at the LGM/Bølling transition. Current work on Bølling-Allerød floating tree-ring series may help to resolve these differences by providing a reliable estimate for length of the Allerød. Age offsets in the LGM and Stage 3 are much larger, reaching $5 \mathrm{kyr}$ or more at $50 \mathrm{kyr}$ BP. At present, these differences remain unresolved.

In light of these disagreements, it appears that ${ }^{14} \mathrm{C}$ records cannot be precisely calibrated from currently available Greenland ice-core data. An indirect calibration may be possible via an emerging consensus among U-Th-dated speleothem records that exhibit Summit-correlative stable isotope 
variations. Alternatively, $\mathrm{K}-\mathrm{Ar}$ and ${ }^{40} \mathrm{Ar} /{ }^{39} \mathrm{Ar}$ dating of the Laschamp geomagnetic event or a suitable volcanic eruption may provide tie points for the Summit chronologies, but only if the dating differences which presently exist in the radiometric data can be resolved. Counting work presently underway on the new NGRIP ice core, or new records derived from in-situ borehole logging, or new $\mathrm{U}-\mathrm{Th}$ or $\mathrm{Ar} / \mathrm{Ar}$ dating measurements, may ultimately provide a means for pinning the ice-core chronologies. Until then, their primary importance for ${ }^{14} \mathrm{C}$ dating (in addition to their unparalleled worth as paleoclimate archives) appears to be that they provide frameworks for interpolation. Unfortunately, such interpolations take place within an overall time interval for which the exact position and length are presently ill-defined.

\section{ACKNOWLEDGMENTS}

This work represents an outsider's look into a complex field of research, and has relied heavily on the assistance of members of the ice-core community. In particular, I wish to thank Sigfus Johnsen, Claus Hammer, and Michael Ram for unpublished data; and Richard Alley, Bob Finkel, Piet Grootes, Claus Hammer, Buford Price, Michael Ram, Minze Stuiver, and above all, Sigfus Johnsen, for patient and detailed responses to numerous questions concerning techniques, data, and chronologies. The manuscript was significantly improved as a result of careful reviews by Richard Alley and Sigfus Johnsen. Any remaining mistakes are mine alone.

\section{REFERENCES}

Alley RB, Meese DA, Shuman CA, Gow AJ, Taylor KC, Grootes PM, White JC, Ram M, Waddington ED, Mayewski PA, Zielinski GA. 1993. Abrupt increase in Greenland snow accumulation at the end of the Younger Dryas event. Nature 362:527-9.

Alley RB, Shuman CA, Meese DA, Gow AJ, Taylor KC, Cuffey KM, Fitzpatrick JJ, Grootes PM, Zielinski GA, Ram M, Spinelli G, Elder B. 1997. Visual-stratigraphic dating of the GISP2 ice core: basis, reproducibility and application. Journal of Geophysical Research 102:26,367-81.

Alley RB, Anandakrishnan S, Jung P. 2001. Stochastic resonance in the North Atlantic. Paleoceanography 16:190-8

Bard E, Raisbeck GM, Jouzel J. 1997. Solar modulation of cosmogenic nuclide production over the last millennium: comparisons between ${ }^{14} \mathrm{C}$ and ${ }^{10} \mathrm{Be}$. Earth and Planetary Science Letters 150:453-62.

Bay RC, Bramall N, Price PB. 2003. Ice logging with light and sound. Eos 84:79-82.

Beck WJ, Richards DA, Edwards RL, Silverman BW, Smart PL, Donahue DJ, Herrera-Osterheld S, Burr GS, Calsoyas L, Jull AJT, Biddulph D. 2000. Extremely large variations of atmospheric ${ }^{14} \mathrm{C}$ concentrations during the last glacial period. Science 292:24538.

Behl RJ, Kennett JP. 1996. Brief interstadial events in the Santa Barbara Basin, NE Pacific, during the past 60 kyr. Nature 379:243-6.

Bender M, Sowers T, Dickson M-L, Orchado J, Grootes P, Mayewski PA, Meese DA. 1994. Climate correlations between Greenland and Antarctica during the past 100,000 years. Nature 372:663-6.
Bond G, Showers W, Cheseby M, Lotti R, Almasi P, deMenocal P, Priore P, Cullen H, Hajdas I, Bonani G. 1997. A pervasive millennial-scale cycle in North Atlantic Holocene and Glacial climates. Science 278: 1256-66.

Brauer A, Endres C, Negendank JFW. 1999. Lateglacial calendar year chronology based on annually laminated sediments from Lake Meerfelder Maar, Germany. Quaternary Science Reviews 61:17-25.

Burns SJ, Fleitmann D, Matter A, Kramers J, Al-Subbary AA. 2003. Indian Ocean climate and an absolute chronology over Dansgaard/Oeschger events 9 to 13 . Science 301:1365-7.

Castagnoli GC, Albrecht A, Beer J, Bonino G, Shen CH, Callegari E, Taricco C, Dittrich-Hannen B, Kubik P, Suter M, Zhu GM. 1995. Evidence for enhanced ${ }^{10} \mathrm{Be}$ deposition in Mediterranean sediments 35 kyr BP. Geophysical Research Letters 22:707-10.

Charles CD, Rind D, Jouzel J, Koster RD, Fairbanks RG. 1994. Glacial-interglacial changes in moisture sources for Greenland: influences on the ice-core record of climate. Science 263:508-11.

Clausen H, Mammer CU, Hvidberg CS, Dahl-Jensen D, Steffensen JP. 1997. A comparison of the volcanic records over the past 4000 years from the Greenland Ice Core Project and Dye-3 Greenland ice cores. Journal of Geophysical Research 102:26,707-23.

Dansgaard W, Johnsen SJ, Clausen HB, Dahl-Jensen D, Gundestrup NS, Hammer CU, Hvidberg CS, Stefffensen JP, Sveinbjörnsdóttir AE, Jouzel J, Bond G. 1993. Evidence for general instability of past climate from a 250-kyr ice-core record. Nature 364:218-20.

Deino A, Curtis GH, Southon J, Terrasi F, Campajola L, 
Orsi G. 1994. ${ }^{14} \mathrm{C}$ and ${ }^{40} \mathrm{Ar} /{ }^{39} \mathrm{Ar}$ dating of the Campanian Ignimbrite, Phlegrean Fields, Italy. ICOG 8, USGS Circular 1107:77.

de Vivo B, Rolandi G, Gans PB, Calvert A, Bohrsson WA, Spera FJ, Belkin HE. 2001. New constraints on the pyroclastic eruptive history of the Campanian Volcanic Plain (Italy). Mineralogy and Petrology 73:4765.

Finkel RC, Nishiizumi K. 1997. ${ }^{10}$ Be concentrations in the Greenland Ice Sheet Project ice core from 3-40 ka. Journal of Geophysical Research 102:26,699-706.

Frank M, Schwarz B, Baumann S, Kubik PW, Suter M, Mangini A. 1997. A 200-kyr record of cosmogenic radionuclide production rate and geomagnetic field intensity from ${ }^{10} \mathrm{Be}$ in globally stacked deep-sea sediments. Earth and Planetary Science Letters 149:1219.

Fuhrer K, Neftel A, Anklin M, Maggi V. 1993. Continuous measurements of hydrogen peroxide, formaldehyde, calcium and ammonium concentrations along the new GRIP ice core from Summit, central Greenland. Atmospheric Environment Part A 27:1873-80.

Genty D, Blamart D, Ouahdi R, Gilmour M, Baker A, Jouzel J, Van-Exter S. 2003. Precise dating of Dansgaard-Oeschger climate oscillations in western Europe from stalagmite data. Nature 421:833-7.

Gillot PY, Labeyrie L, Laj C, Valladas G, Guerin G, Poupeau G, Delibrias G. 1979. Age of the Laschamp paleomagnetic excursion revisited. Earth and Planetary Science Letters 42:444-50.

Gow AJ, Meese DA, Alley RB, Fitzpatrick JJ, Anandakrishnan S, Woods GA, Elder BC. 1997. Physical and structural properties of the Greenland Ice Sheet Project 2 ice core: a review. Journal Geophysical Research 102:26,569-75.

Greenland Summit Ice Cores [CD-ROM]. 1997. Available from the National Snow and Ice Data Center, University of Colorado at Boulder, and the World Data Center-A for Paleoclimatology, National Geophysical Data Center, Boulder, Colorado. Contents available on the Web at http://www.ngdc.noaa.gov/paleo/icecore/ greenland/summit/.

Gronvold K, Oskarsson N, Johnsen S, Clausen HB, Hammer CU, Bond G, Bard E. 1995. Ash layers from Iceland in the Greenland GRIP ice core correlated with ocean and land sediments. Earth and Planetary Science Letters 135:149-55.

Grootes PM, Stuiver M. 1997. Oxygen-18/16 variability in Greenland snow and ice with $10^{-3}$ to $10^{5}$-year time resolution. Journal of Geophysical Research 102: 26,455-70.

Grootes PM, Stuiver M, White JW, Johnsen S, Jouzel J. 1993. Comparison of oxygen isotope results from the GISP2 and GRIP Greenland ice cores. Nature 366: $552-4$

Hammer CU, Clausen HB, Tauber H. 1986. Ice-core dating of the Pleistocene/Holocene boundary applied to the calibration of the ${ }^{14} \mathrm{C}$ time scale. Radiocarbon 28(2A):284-91.

Hammer CU, Andersen KK, Clausen HB, Dahl-Jensen D, Hvidberg CS, Iversen P. 1997. "The Stratigraphic Dating of the GRIP Ice Core," special report, Geophysics Department, Niels Bohr Institute for Astronomy, Physics, and Geophysics. Copenhagen: University of Copenhagen.

Hughen KA, Southon JR, Lehman S, Overpeck JT. 2000. Synchronous radiocarbon and climate shifts during the last deglaciation. Science 290:1951-4.

Hughen K, Lehman S, Southon J, Overpeck J, Marchal O, Herring C, Turnbull J. 2004. ${ }^{14} \mathrm{C}$ activity and global carbon cycle changes over the past 50,000 years. Science 303:202-7.

Johnsen SJ, Clausen HB, Dansgaard W, Fuhrer K, Gundestrup N, Hammer CU, Iversen P, Jouzel J, Stauffer B, Steffensen JP. 1992. Irregular glacial interstadials recorded in a new Greenland ice core. Nature 359: 311-3.

Johnsen SJ, Clausen HB, Dansgaard W, Gundestrup N, Hammer CU, Andersen U, Anderson KU, Hvidberg CS, Dahl-Jensen D, Steffensen JP, Shoji H, Sveinbjörnsdóttir AE, White J, Jouzel J, Fisher D. 1997. The $\delta^{18} \mathrm{O}$ record along the Greenland Ice Core Project deep ice core and the problem of possible Eemian climate instability. Journal of Geophysical Research 102:26,397-410.

Johnsen SJ, Clausen HB, Jouzel J, Schwander J, Sveinbjörnsdóttir AE, White J. 1999. Stable isotope records from Greenland deep ice cores: the climate signal and the role of diffusion. In: Wettlaufer JS, Dash JG, Untersterner $\mathrm{N}$, editors. Ice Physics and the Natural Environment. Berlin: Springer-Verlag. p 89-107.

Johnsen SJ, Dahl-Jensen D, Gundestrup N, Steffensen J, Clausen H, Miller H, Masson-Delmotte V, Sveinbjörnsdóttir AE, White J. 2001. Oxygen isotope and paleotemperature records from six Greenland ice-core stations: Camp Century, Dye-3, GRIP, GISP2, Renland and NorthGRIP. Journal of Quaternary Science 16:299-307.

Kocharov GE. 1992. ${ }^{14} \mathrm{C}$ and astrophysical-geophysical phenomena. In: Taylor RE, Long A, Kra RS, editors. Radiocarbon After Four Decades. Berlin: SpringerVerlag. p 130-45.

Kromer B, Spurk M. 1998. Revision and tentative extension of the tree-ring based ${ }^{14} \mathrm{C}$ calibration 9200 11,855 cal BP. Radiocarbon 40(3):1117-25.

Lacasse C, Sigurdsson H, Carey S, Paterne M, Guichard F. 1996. North Atlantic deep-sea sedimentation of Late Quaternary tephra from the Iceland hotspot. Marine Geology 129:207-35.

Levi S, Audunsson H, Duncan RA, Kristjansson L, Gillot P-Y, Jakobsson SP. 1990. Late Pleistocene geomagnetic excursion in Icelandic lava: confirmation of the Laschamp excursion. Earth and Planetary Science Letters 96:443-57. 
Lowe JJ, Hoek WZ, INTIMATE group. 2001. Interregional correlation of paleoclimate records for the last glacial-interglacial transition: a protocol for improved precision recommended by the INTIMATE project group. Quaternary Science Reviews 20:117587.

Martinson DG, Psias NG, Hays JD, Imbrie J, Moore TCJ, Shackleton NJ. 1987. Age dating and the orbital theory of ice ages: development of a high-resolution 0 to 300,000-year chronostratigraphy. Quaternary Research 27:11-29.

Meese DA, Alley RB, Gow AJ, Groote PM, Mayewski PA, Ram M, Taylor KC, Waddington IE, Zielinski GA. 1994. Preliminary depth-age scale of the GISP2 ice core, CRREL Special Report 94-1. Hanover, New Hampshire (USA): Cold Regions Research and Engineering Laboratory.

Meese D, Gow AJ, Alley RB, Zielinski GA, Grootes PM, Ram M, Taylor KC, Mayewski PA, Bolzan JF. 1997. The Greenland Ice Sheet Project 2 depth-age scale: methods and results. Journal of Geophysical Research 102:26,411-23.

Peterson LC, Haug GH, Hughen KA, Rohl U. 2000. Rapid changes in the hydrologic cycle of the tropical Atlantic during the last glacial. Science 290:1947-51.

Raisbeck GM, Yiou F, Fruneau M, Loiseaux JM, Lieuvin M, Ravel JC. 1981. Cosmogenic ${ }^{10} \mathrm{Be} /{ }^{7} \mathrm{Be}$ as a probe of atmospheric transport processes. Geophysical Research Letters 8:1015-8.

Rahmstorf S. 2003. Timing of abrupt climate change: a precise clock. Geophysical Research Letters 30(10): 1510-3.

Ram M, Illing M. 1994. Polar ice stratigraphy from laserlight scattering: scattering from meltwater. Journal of Glaciology 40:504-8.

Ram M, Illing M, Weber P, Koenig G, Kaplan M. 1995. Polar ice stratigraphy from laser-light scattering: scattering from ice. Geophysical Research Letters 22: $3525-7$.

Ram M, Donarummo J, Sheridan M. 1996. Volcanic ash from Iceland $\sim 57,300 \mathrm{yr}$ BP eruption found in GISP2 (Greenland) ice core. Geophysical Research Letters 23:3167-9.

Ram M, Koenig G. 1997. Continuous dust concentration profile of pre-Holocene ice from the Greenland Ice Sheet Project 2 ice core: dust stadials, interstadials and the Eemian. Journal of Geophysical Research 102: 26,641-8.

Ram M, Donarummo J, Stolz MR, Koenig G. 2000. Calibration of laser-light scattering measurements of dust concentrations for Wisconsin GISP2 ice using instrumental neutron activation analysis of aluminum: results and discussion. Geophysical Research Letters 105:24,731-8.

Robinson C, Raisbeck, Yiou F, Lehman B, Laj C. 1995. The relationship between ${ }^{10} \mathrm{Be}$ and geomagnetic field strength records in central North Atlantic sediments during the last $80 \mathrm{ka}$. Earth and Planetary Science Letters 136:551-7.

Ruddiman WF, MacIntyre A. 1984. Ice-age thermal response and climatic role of the surface Atlantic Ocean, $40^{\circ} \mathrm{N}$ to $63^{\circ} \mathrm{N}$. Geological Society of America Bulletin 95:381-96.

Ruddiman WF. 2003. Orbital insolation, ice volume, and greenhouse gases. Quaternary Science Reviews 22: 1597-629.

Shackleton NJ. 2000. The 100,000-year ice-age cycle identified and found to lag temperature, carbon dioxide and orbital eccentricity. Science 289:1897-902.

Sigurdsson H, McIntosh WC, Dunbar N, Lacasse C, Carey SN. 1998. Thorsmork Ignimbrite in Iceland: possible source of the North Atlantic Ash Zone 2. Eos Transactions, AGU, Spring Meeting Supplement 79: S377.

Southon JR. 2002. A first step to resolving the GISP2 and GRIP ice-core chronologies, 0-14,500 yr BP. Quaternary Research 57:32-7.

Sowers T, Bender M, Labeyrie LD, Jouzel J, Raynaud D, Martinson D, Korotkevich YS. 1993. 135,000 year Vostok-SPECMAP common temporal framework. Paleoceanography 8:737-66.

Spotl C, Mangin A. 2002. Stalagmite from the Austrian Alps reveals Dansgaard-Oeschger events during isotope stage 3: implications for the absolute chronology of Greenland ice cores. Earth and Planetary Science Letters 203:507-18.

Spurk M, Friedrich M, Hofmann J, Remmele S, Frenzel B, Leuschner H, Kromer B. 1998. Revisions and extensions of the Hohenheim oak and pine chronologies: new evidence about the timing of the Younger Dryas/ Preboreal transition. Radiocarbon 40(3):1107-16.

Stuiver M, Braziunas TF. 1993. Sun, ocean, climate and atmospheric ${ }^{14} \mathrm{CO}_{2}$ : an evaluation of causal and spectral relationships. The Holocene 3:289-305.

Stuiver M, Grootes PM, Braziunas TF. 1995. The GISP2 $\delta^{18} \mathrm{O}$ climate record of the past 16,500 years and the role of the sun, ocean and volcanoes. Quaternary Research 44:341-54.

Stuiver M, Reimer PJ, Bard E, Beck JW, Burr GS, Hughen KA, Kromer B, McCormac G, van der Plicht J, Spurk M. 1998. IntCa198 radiocarbon age calibration, 24,000-0 cal BP. Radiocarbon 40(3):1041-83.

Stuiver M, Grootes PM. 2000. GISP2 oxygen isotope ratios. Quaternary Research 53:277-84.

Taylor KC, Alley RA, Lamorey G, Mayewski P. 1997. Electrical measurements on the Greenland Ice Sheet Project 2 Core. Journal of Geophysical Research 102: 26,511-7.

Ton-That T, Singer B, Paterne M. 2001. ${ }^{40} \mathrm{Ar} /{ }^{39} \mathrm{Ar}$ dating of the latest Pleistocene (41 ka) marine tephra in the Mediterranean Sea: implications for global climate records. Earth and Planetary Science Letters 184: 645-58.

van Krefeld S, Sarnthein M, Erlenkreuser H, Jung S, 
Nadeau MJ, Pflaumann U, Voelker A. 2000. Potential links between surging ice sheets, circulation changes and the Dansgaard-Oeschger cycles in the Irminger Sea, 18-60 kyr. Paleoceanography 15:425-42.

Voelker AHL, Sarnthein M, Grootes PM, Erlenkreuser H, Laj C, Mazaud M, Nadeau MJ, Sleicher M. 1998. Correlation of marine ${ }^{14} \mathrm{C}$ ages from the Nordic seas with the GISP2 isotope record: implications for ${ }^{14} \mathrm{C}$ calibration beyond $25 \mathrm{ka}$ BP. Radiocarbon 40(1):51734.

von Grafenstein U, Erlenkreuser H, Brauer A, Jouzel J, Johnsen S. 1999. A mid-European decadal isotopeclimate record from 15,500 to 5000 years BP. Science 284:1654-7.
Wang YJ, Cheng H, Edwards RL, An ZS, Wu C-C, Dorale JA. 2001. A high-resolution absolute-dated late Pleistocene monsoon record from Hulu Cave, China. Science 292:2345-8.

Yiou F, Raisbeck GM, Baumgartner S, Beer J, Hammer C, Johnsen S, Jouzel J, Kubik PW, Lestringuez J, Stievenard M, Suter M, Yiou P. 1997. ${ }^{10} \mathrm{Be}$ in the Greenland Ice Core Project ice core at Summit, Greenland. Journal of Geophysical Research 102:26,78394.

Zielinski GA, Mayewski PA, Meeker LD, Whitlow S, Twickler MS. 1996. A 110,000-yr record of explosive volcanism from the GISP2 (Greenland) ice core. Quaternary Research 45:109-18. 